\title{
EuroGeoSurveys
}

\section{The national geological surveys combine to map a way forward for the total environment of the European Union}

EuroGeoSurveys is a new European association constituted in 1995 by the Directors of the 15 national geological surveys of the European Union and includes the Norwegian Geological Survey. It has developed from a previous grouping of 21 Western European geological surveys (WEGS) but has a closer-knit, more executive structure and a new mission to enable it to address European issues of common interest to the surveys. It will provide a permanent network between the surveys and promote the contribution of geoscience to improving the quality of life in the European Union and farther afield. EuroGeoSurveys plans to use the huge information resources of the national geological surveys, gathered over an average of 119 years in each country, and the expertise of 6000 specialist staff, to provide focused advice to European Union decision-makers and policy planners on realistic future options for issues involving natural resources, the environment and natural hazards. EuroGeoSurveys plans to propose scenarios for concerted action in these fields by surveys, decision-makers from the European Union institutions, governments and industrial and environmental organisations. A Bureau, opened in Brussels in January 1996, will promote continuous information exchange with these bodies.

\section{Introduction}

In the European Union, issues relating to the extraction of resources, environmental protection and natural hazards are increasingly having to be addressed on a trans-national basis. For historical reasons however most of the geoscience data relevant to such issues has been collected and made available on a national basis. EuroGeoSurveys is a new European association constituted by the Directors of the national geological survey organisations of each of the 15 member states of the European Union which will help to address geoscience issues on a trans-national basis. Membership of EuroGeoSurveys is also open to the surveys of European states associated with the European Union and in June 1996 the Norwegian Geological Survey joined EuroGeoSurveys on this basis (Figure 1).

\section{Development and mission}

In 1970 the Directors of several national geological surveys in Europe conceived the idea of forming an association to promote the important role of the geosciences in all aspects of everyday life in Europe. In 1971, 21 Western European geological surveys formed a discussion group (known as WEGS) which later contributed to the

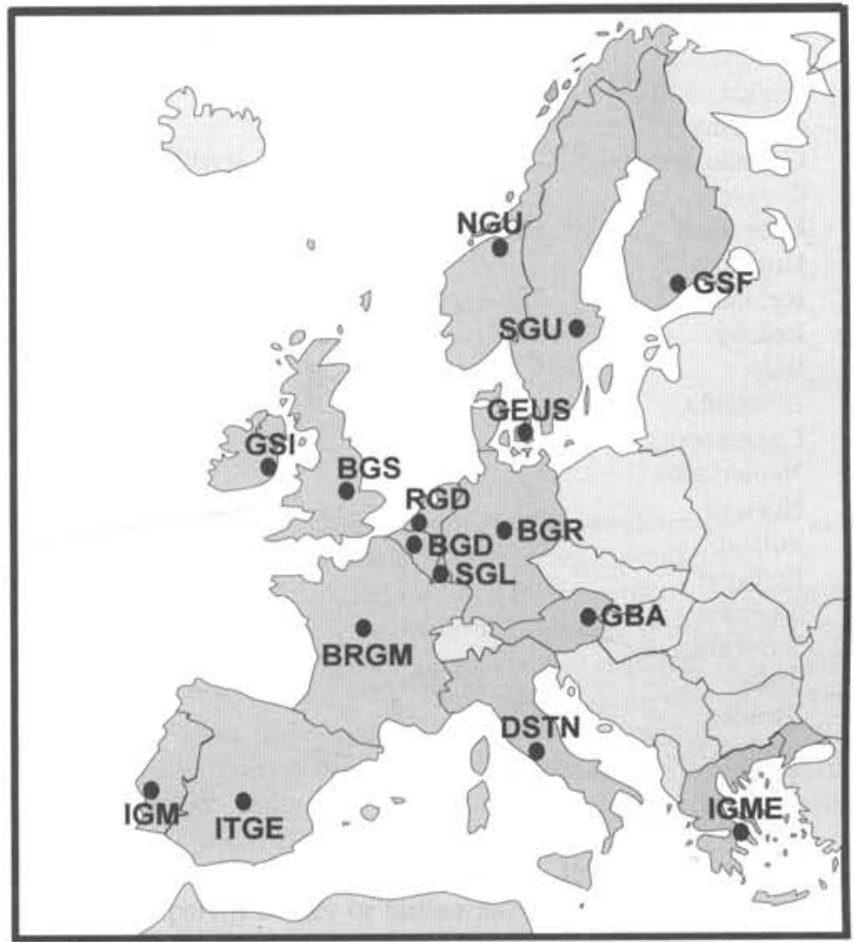

Figure 1 The 16 member organisations of EuroGeoSurveys.

Austria-GBA
Geologische Bundesanstalt
Belgium_BGD-SGB
Belgian Geological Survey
Denmark - GEUS
Danmarks og Grønlands
Geologiske Undersøgelse
Finland-GSF
Geological Survey of Finland
France-BRGM
Bureau de Recherches
Géologiques et Minières
Germany-BGR
Bundesanstalt für Geowis-
senschaften und Rohstoffe
Greece-IGME
Institute of Geology and
Mineral Exploration
Ireland-GSI
Geological Survey of Ireland

wider Forum of European Geological Surveys (FOREGS) which included Survey membership from most Central and Eastern European countries (Table 1).

The founding 21 surveys of WEGS completed a major feat of scientific coordination in 1992 by publishing a comprehensive and well-illustrated 325-page statement by 231 contributors on 'Geology and the environment in Western Europe' aimed at the intelligent layman (Lumsden, 1992). A foreword to the book by Mrs Gro Harlem Brundtland, the Prime Minister of Norway, welcomed the surveys' 
Table I Membership of WEGS, FOREGS and EuroGeoSurveys.

\begin{tabular}{|c|c|c|c|}
\hline Founded & $\begin{array}{l}\text { WEGS } \\
(21) \\
1971\end{array}$ & $\begin{array}{c}\text { FOREGS } \\
(28) \\
1992\end{array}$ & $\begin{array}{c}\text { EuroGeoSurveys } \\
\text { (16) } \\
1995\end{array}$ \\
\hline $\begin{array}{l}\text { Albania } \\
\text { Austria } \\
\text { Belgium } \\
\text { Cyprus } \\
\text { Czech Republic } \\
\text { Denmark } \\
\text { Finland } \\
\text { France } \\
\text { Germany } \\
\text { German States } \\
\text { Greece } \\
\text { Greenland } \\
\text { Hungary } \\
\text { Iceland } \\
\text { Ireland } \\
\text { Italy } \\
\text { Lithuania } \\
\text { Luxembourg } \\
\text { Netherlands } \\
\text { Norway } \\
\text { Poland } \\
\text { Portugal } \\
\text { Slovakia } \\
\text { Slovenia } \\
\text { Spain } \\
\text { Sweden } \\
\text { Switzerland } \\
\text { Turkey } \\
\text { United Kingdom }\end{array}$ & $\begin{array}{l}0 \\
0 \\
0 \\
0 \\
0 \\
0 \\
0 \\
0 \\
0 \\
0 \\
0 \\
0 \\
0 \\
0 \\
0 \\
0 \\
0\end{array}$ & $\begin{array}{l}0 \\
0 \\
0 \\
0 \\
0 \\
0 \\
0 \\
0 \\
0 \\
0 \\
0 \\
0 \\
0 \\
0 \\
0 \\
0 \\
0 \\
0 \\
0 \\
0 \\
0 \\
0 \\
0 \\
0 \\
0 \\
0 \\
0 \\
0 \\
0\end{array}$ & $\begin{array}{c}0 \\
0 \\
0 \\
0 \\
0 \\
0 \\
\text { (with Germany) } \\
0 \\
\text { (with Denmark) }\end{array}$ \\
\hline
\end{tabular}

initiative and emphasised that the geosciences "can be the key to overcoming or avoiding many of the problems which face us in dealing with the need to build the economy whilst safeguarding the environment.' The preface of editor Innes Lumsden pointed out that communications and exchanges of information between the organisations had developed so effectively that the relevant data and expertise available in the Geological Surveys could be readily brought to bear on any national or international environmental study or problem in Western Europe and adjacent and associated territories.' Lumsden identified the greatest obstacle to solving the environmental and geoscience problems facing humankind as "ensuring that the non-geologists, the politicians, the decision-makers, the industrialists, the planners and the laymen recognise the scale and relevance of the data and expertise that exist, and that they understand when and how to achieve their most effective application to everyday problems in the environment, whatever their size. All too often geology is not applied when it should be, and problems become disasters or they are overcome or ameliorated at unnecessary cost.'

The production of the WEGS volume marked a key stage in the development of EuroGeoSurveys. It also highlighted the need for priority future actions for the further improvement of accessibility to and exchange of geoscience information in order to enable more enlightened management and control of the environment and the establishment of realistic shared standards for the evaluation of environmental problems. Furthermore, it emphasised that the geological surveys should be mandated by the highest levels of government in view of the critical importance of these tasks for the long-term benefit of mankind in a widening, increasingly more populated, Europe.

By autumn 1992, the Directors of surveys within the European Union felt that it was time to develop a new, closer-knit, and more executive structure (called EuroGeoSurveys) which could concert the input of the geosciences to specific European Union matters and directly engage the national authorities, the European Commission and the European Parliament at a senior level. The members of EuroGeoSurveys saw the association as providing for the first time a European body qualified to give the European Union balanced and authoritative geoscientific policy advice or decision support in the important areas of earth resources, total environment, and natural hazards. Eurogeosurveys would not duplicate the work of FOREGS which would continue its essential role of providing the wider European context.

The Directors of the member surveys formulated the following mission and objectives for EuroGeoSurveys:

- to bring together the geological surveys, enabling them to jointly address European issues of common interest;

- to provide a permanent network between the geological surveys and a common, but not unique, gateway to each of the surveys and their national networks;

- to assist the European Union to obtain joint technical advice from the geological surveys of the member states;

- to promote, wherever appropriate, the contribution of geoscience to European Union affairs and action programmes;

- to initiate, develop, and promote geoscience inputs to co-ordinated bilateral and multilateral programmes within European and other countries.

In autumn 1992 these objectives were discussed with Martin Bangemann, the European Commissioner with responsibility for industry. Encouraged by the interest he expressed in their concept of a joint association of European Geological Surveys, the organisation proceeded over the next two years to draw up formal statutes from a memorandum of understanding and it was decided that the association should be registered in France with a working office or bureau to be based close to the European institutions in Brussels. During this period EuroGeoSurveys organised its first scientific meeting at Elincourt Sainte-Marguerite in May 1994 as a workshop on mineral resources and sustainable development for 47 European experts from the surveys, national representations and industrial and environmental organisations. This meeting was funded by BGS, BRGM, DG III (Industry) of the European Commission, the UK Department of the Environment, the French Embassy in London, and the Paris office of the British Council. Thirty five papers were presented at the workshop, which raised many issues that are now part of the ongoing EuroGeoSurveys agenda.

In September 1995, all 15 geological survey Directors of the European Union met in Dublin to sign the EuroGeoSurveys statutes and to select from senior survey geologists a Secretary General to open and run a Brussels Bureau to provide a working interface with the European institutions. The Bureau opened its doors on 8 January 1996 close to rond-point Schuman in a location close to key European offices.

\section{The structure and aims of EuroGeoSurveys}

EuroGeoSurveys business is managed by an executive committee which rotates each calendar year and consists of three Directors and a co-opted member, one of the Directors taking the office of President for the year. The President 1996 is Dr Peter Cook, Director of the British Geological Survey. The general meeting of all Directors meets twice a year and is the final decision-making body. A third group, the task force, consists of co-opted senior survey staff and is responsible for drafting key documents such as the statutes or position papers on specific geoscience topics. The activities of EuroGeoSurveys are funded by annual subscriptions from members.

A Secretary General, currently Dr Richard Annells, runs the general business of the bureau in Brussels. He drafts a rolling-forward plan for EuroGeoSurveys activities in close consultation with the executive committee, task force and general meeting, based on a balance between priority pan-European issues as perceived by the geological surveys and the European institutions. An important part 


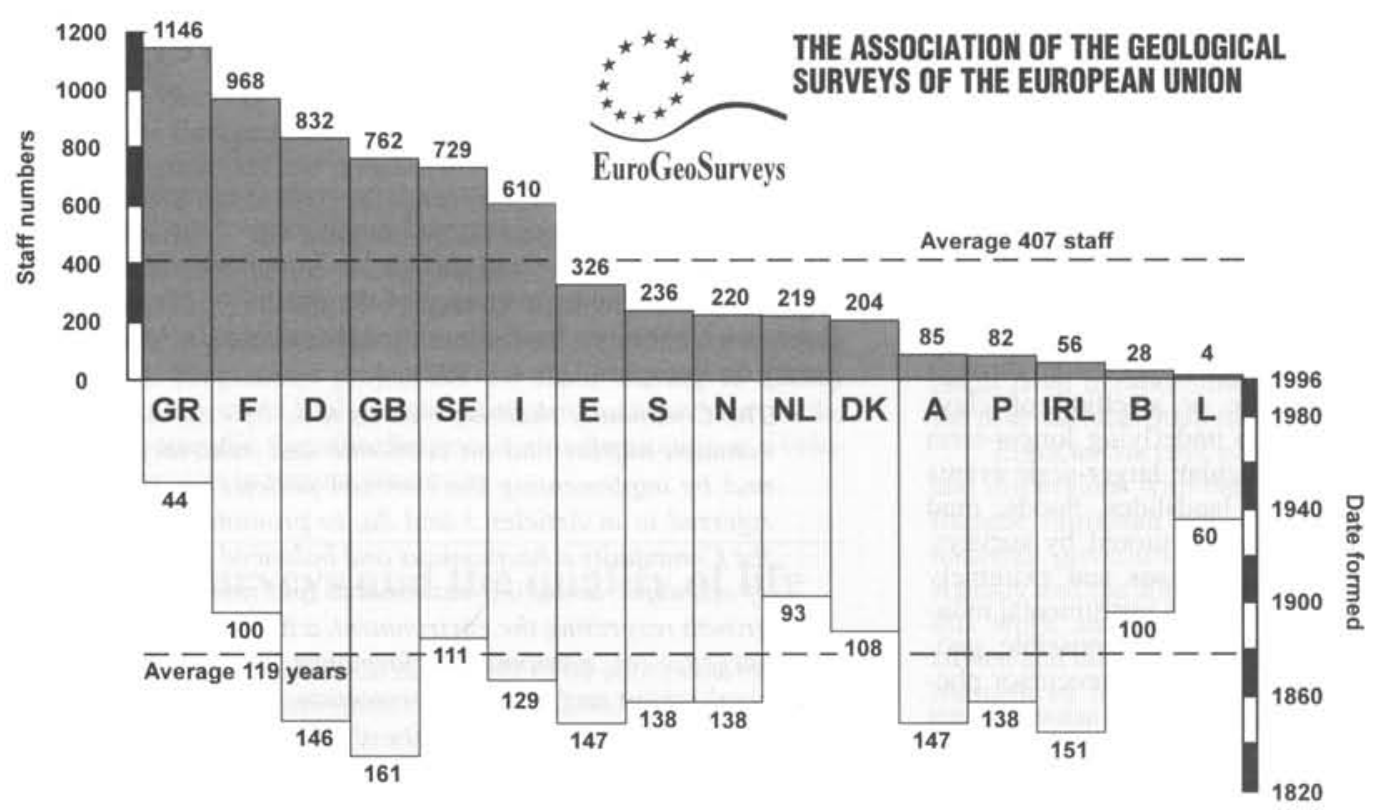

Figure 2 The numbers of employees in the member geological surveys of EuroGeoSurveys and the age and date of foundation of each survey.

(Based on mid-1995 figures compiled by B Prévosteau, BRGM).

of the Secretary General's work is to build up contacts with officials in the European Commission and Parliament and to stimulate a twoway flow of information between them and the geological surveys. $\mathrm{He}$ is also the central point of a number of electronic topic networks of survey experts who contribute expertise on specific issues of interest to EuroGeoSurveys as and when required. In this context, the Secretary General also helps to define relevant geoscience issues by liaising with other Europe-wide organisations such as the mineral industry and environmental associations based in Brussels as well as national representations. The Secretary General can be reached at:

EuroGeoSurveys Bureau,

rue Breydel 40, B-1040 Brussels

Phone +32 2282 0604: fax +32 22801979 ;

e-mail: RN.Annells@pophost.eunet.be;

Internet home page: http//:www.eurogeosurveys.ac.uk

\section{The geological surveys}

Each member survey of EuroGeoSurveys is a governmental or quasi-governmental institution usually funded to enable it to it report each year to its national government or governing board on the state of the country's landmass and earth resources. The main responsibility of most geological surveys is thus to formulate and keep under constant review a core programme dictated by national needs (e.g. systematic regional geological, geophysical or geochemical mapping and report compilation on national topographic grids) funded in-country by national agencies and supported by relevant applied research in order to provide the information and options for action needed by policy makers. This requires a continuous, consistent and objective style of information gathering and monitoring work, which goes back in some cases over 160 years (Figure 2) and makes the Surveys prime national authorities or topic centres on detailed resource and environmental information and policy-related questions. Some surveys have earned the high recognition of being selected as international quality centres: for instance by the World Health Organisation in fields such as groundwater investigation.

In addition to the data gathered by their own staff, many of the surveys also curate other public- or private-sector geoscience information banks and are permitted to use such information in a generic way to assist research, survey and monitoring programmes. They have commonly developed close communication links with central government and are an obvious mechanism to help the European Union preserve consistency and a correct relationship of subsidiarity between national and European policies in areas where all sides require cost-efficiency and issue-relevant long-term planning.

The proportion of funding received from central government by each geological survey varies between countries. For example, the British Geological Survey (BGS) receives less than half of its funding from central government for 'core' programmes of strategic science of long-term importance to the United Kingdom, with the remainder being earned from external contracts with other government departments, industry, development agencies and the European Communities (Cook, 1996). This basic mode of funding is common and most surveys now seek extra revenue from national agencies outside their parent bodies or farther afield in the developing countries through international competition or collaboration with other research organisations and industry in programmes funded by the European Communities, the United Nations, the World Bank and other agencies.

\section{The resources of EuroGeoSurveys}

\section{Information}

The prime resource of EuroGeoSurveys is geoscience information, based on very extensive banks of data and maps compiled over an average period of 119 years in each member state (Figure 2). Every Survey has an intimate geological, geophysical and geochemical knowledge of its own part of the European landmass and its seas, gathered directly from outcrops, boreholes, mines and quarries, or indirectly from ships, aircraft and satellites. The processed data are available in a variety of forms which, together, form a vital part of each country's national information heritage. It is for this reason that the surveys which gather the information have been publicly rather than privately funded organisations up to the present time.

Increasingly the information resources are being offered as map or imagery products based on GIS packages and tailored to specific user requirements. This trend has resulted from three important factors. Firstly, geoscience information, even when in map form, requires specialist skills in three-dimensional visualisation and in the interpretation of data derived from scattered outcrop or drill hole data. Geoscience maps, unlike topographic maps, cannot be compiled from large numbers of directly measured points because of the paucity of outcrops, many of which are further obscured by agricultural or construction activity. Secondly, the geoscience user market has become highly diverse. Information is now in constant demand 
from construction, environmental and waste disposal engineers, mineral and hydrocarbon exploration companies, water resource managers, disaster relief agencies, insurance companies, ant and architectural restorers, archacologists, forensic experts and tourists. Thirdly, much geoscience information is now required in real-time modes in order 10 predict the behaviour of natural processes or systems which respond to short-term scasonal climatic variations or local, small-scale deformations of the Earth's crust. Examples are the subsurface circulation of groundwater or methane gas in different rock formations or around buried waste materials. the circulation of environmental pollutunts (whether natural or man-made) through groundwater, and the seasonal shrinkage or swelling of elays beneath the foundations of buildings. The underlying longer-term carth processes which result in more spectacular, larger-scale events such as earthquakes, volcanic eruptions, landslides, floods, mud flows and coastal crosion also need to be monitored by surveys. Although the long periodicity of these processes and extremely small inherent percentage crors in high-precision instrumental monitoring make the exact prediction of event timing impossible, geological surveys can in some cases detect patterns of precursor phenomena which give time for communitics at risk to evacuale danger areas.

\section{Staff and capabilities}

EuroGeosurveys is backed by a tolal European staff resource of 6500 scientists, technical support and administrative personnel (Figure 2), the average staft complement of a survey being about 406 peoplc. While each survey strives to maintain practical excellence in basic geoscience research, their main remit is the applied rather than the academic end of science. The basic survey scientific disciplines followed within EuroGeosurveys include land-based and marine gcology, stratigraphy and palacontology, geochemistry and mineralogy, geology of hydrocatbon and geothermal energy sources. mineral exploration and commodity work, geology of radioactive materials and radiation protection. Watste disposal, engineering geology, geophysics and remote sensing, hydrogeology, soil science, resource and environmental statistics, information lechnology and computer modelling. Important support activities include analytical services for minerals, rocks and waters, museum and library management, map and report editing and publication, marketing and exhibitions and the construction and operation of a wide variety of field and laboratory equipment. Survey scientists commonly contribute to the development of the wider geoscience research and education community as visiting professors, lecturers and postgraduate supervisors at universities and in many other ways. These collaborative activities, as well as the foreign aid programmes mentioned below, place the scope of EuroGeoSurveys work in a truly international context that covers over 140 countries worldwide.

\section{International activities of the geological surveys}

The generic nature of much geoscience and the wide geographic distribution of rock types makes knowledge and methods developed in Europe applicable any where in the world. The surveys long association with the policy and implementation of their own countries overseas development agencies programmes, as explorers, trainers, institution-builders and agents of technology transfer to geological surveys in the less-developed countries of the world makes them strong contenders in the Furopean-funded developing world programmes in the African, Caribbean, Pacific, Asian, I atin American and Mediterranean regions. Most of the geological survey institutions of the developing world countries were originally set up by organisations which are now members of EuroGeosurveys.

The newly independent countries of central and eastern Europe and the former Soviet Union are target areas for EuroGeoSurveys cooperative work, and over the years the EuroGeoSurveys members have developed long-standing scientific contacts with their counterparts through activitics such as FOREGS and international conferences in diverse specialist fields.

\section{The relevance of EuroGeoSurveys to the European Union}

The ability of geological surveys to provide continuous, fully contexted and accessibly documented monitoring of the total environment at and beneath the land surface has important and far-reaching implications for the maintenance of the quality of life to which the European institutions have committed themselves in Article 2 of the Treaty on European Union (1992):

The Community shall have as its task, by establishing a commen market and an economis and monetary union and by implementing the common policies or activities referred to in Articles 3 and $3 a$, to promote throughout the Commanity a harmonious and balanced development of economic activities, sustainable and non-inflationary growth respecting the entiromment, a high dagree of comvergence of economic performance, a high level of emploment and of social protection, the raising of the standard of living and quality of life, and economic and social cohesion and solidarity among Member State's.

Article 3 of the same treaty specifics that the European Union must achicve (among other tasks):

- a policy in the sphere of the environment;

- the strengthening of the competitiveness of Community industry:

- the promotion of research and technological development;

- a policy in the sphere of development cooperation;

- measures in the sphere of energy, civil protection and lourism.

The Communities framework programmes of research and development mounted since 1984 and making up the largest single source of funds disbursed directly from European Commission offices are centred on the topics in Article 3. One concern that EuroGeosurveys has is that the scale of funding for specific research in geoscience has declined during the third and fourth framework programmes despite its fundamental importance to basic industries in raw materials and energy, the management of water and the environment and the direct relevance of these issues in maintaining European prosperity, public health and safety and general quality of life. This trend can be clearly discerned in the industrial and materials technologies programme (BRITE-EURAM), where the proportion of funds available for research relevant to mineral exploration is now very low. The non-nuclear energy progranme (JOUL.E) has shifted its attention away from the geoscience of hydrocarbon basins and geothermal energy despite the importance of such energy sources 10 Europe. More recently, the planned run-down of the non-framework European coal and steel community (ECSC) budget for coal and steel-related research renoves other important areas for geoscience inputs. The environment and climate, marine science and technology programmes do offer scope for the geosciences, as does the training and mobility for rescarchers (TMR) programme which is not founded on any specific discipline and provides mostly for young research fellows or large host institutions. Apart from the environment-water and maritime systems of the future task forces, the new research-industry task forces devised by the Commission are so broad in scope and end-product oriented that they are unlikely to foster the development of new European technology in essential supply-end industries such as exploration which have to find the special materials to build and power the aircraft, cars and trains of the future. These issues would benefit from more support for geoscience research and enhanced information flow to users in the European raw materials, energy and water industries so that these activities can keep up with new technologies developed in non-European industrialised cotntries. Without this the European Union will have to place increased reliance on imported fuel and non-fuel raw materials and on technologies or technologists imported from outside the Union. Some European Union technologies are already falling behind in world arenas, such as deep mining, airborne radiometric surveying, 
remote sensing from satellite platforms and the exploitation of geothermal energy.

EuroGeoSurveys is therefore ready to provide targeted advice to areas of the European Commission involved in the formulation of balanced programmes and policies in fields such as mineral, water, energy and soil resources, pollution, natural hazard and waste disposal management. The association has already begun work in this sphere by providing advice to DG III (Industry) on the drawing up of a European minerals inventory suitable for use by industrial and government users in a realistic European dimension, and in formulating a Framework Programme project for the rapid sharing of Survey geoscience information with industry, governments and the public by electronic transfer. EuroGeoSurveys is also developing as a vehicle for cooperation in remote sensing.

\section{EuroGeoSurveys and the quality of life}

There is an obvious geoscience imbalance to be addressed by EuroGeoSurveys in the environmental field within sustainable management schemes. Low priority is accorded to addressing the dominant physical and chemical influence of underlying rock types and soils in defining the natural human habitat of Europe. For example, the European Commission's present goal of achieving and legislating for uniform standards of soil or lake-water acidity across the length and breadth of Europe needs examination as it does not take into account the circumstance that certain types of acidification and pollution of land and waters are naturally produced by the mineral chemistry of the containing bedrock quite independently of any human activity, and are responsible for natural 'geodiversity'.

Quality of life is intimately related to land use. Geoscientific field staff are well trained in observation and the synthesis of information, increasingly aided by the power of modern information technology and airborne or satellite technology to provide synoptic, realtime and multi-temporal views of wide areas of the Earth's surface and the uses to which they are put.

Most of the world's human settlements are built on Quaternary deposits because they are the most widely encountered surface formations, commonly containing or located close to water supplies and presenting soft, often level surfaces in which it is easy to dig wells and foundations. B P Hageman, former Director of the Geological Survey of the Netherlands, frequently drew attention to the impact on society of these Quaternary deposits and processes. While he acknowledged that geologists themselves were partly to blame for not communicating the results of their work to the public side of their work, he observed that:

The vast majority of politicians and decision-makers are drawn from business, economics, and law. Almost by definition, these people have never received any formal education in aspects of the natural sciences that are of decisive importance to human life. On the contrary, their world with its ever elastic legal and policy processes differs completely from the one dominated by the hard facts of nature, dealing with places, processes, qualities and quantities. This traditional background prevents politicians and decision-makers from understanding the importance of natural resources and from incorporating the harsh realities of nature into their systems. (Hageman, 1987, p.47).

\section{EuroGeoSurveys and the future of Europe}

Hageman (1987) expressed very concisely the importance of raising the level of understanding of the geosciences in all sectors of the population:
The Earth's crust is the only source of water, fertile land, building materials, and stable sites for development, as well as the traditional energy and mineral resources. ... responsible and beneficial management, based on an adequate inventory of earth resources, must be the starting point for all environmental planning and for ensuring human survival.

Through their national and international programmes the geological surveys of the European Union have developed a detailed understanding of the dangers and environmental blight likely to result from irresponsible management of the solid earth, including the near-surface Quaternary deposits and aquifers.

EuroGeoSurveys plans to organise topic-focused presentations and discussions with the European Commission, the European Parliament, European industrial and environmental associations and the national governments. Links with the European Environment Agency and the Joint Research Centre will play an important part in this work and interactions will be used to provide professional advice and undertake projects to promote the well-being of the environment of the European Union and its people now and for the future.

\section{Acknowledgements}

This article has benefited from critical reading by Dr Peter Cook, Dr Cor van Staalduinen, Dr Ole Winther Christensen, Dr Luis Delgado and Professor Dr-lng F-W Wellmer, and the author gratefully acknowledges discussions with many other colleagues from EuroGeoSurveys members. Continuing dialogue with a widening circle of contacts in the European Commission and associations such as Euromines, Eurométaux and the European Federation of Geologists has also contributed much to the article. Thanks go to Dan Sheath (BGS) for drafting the diagrams and to Dominique Floridor and Anne-Françoise Martin for processing the text.

\section{References}

Cook, P J and Johan, Z, eds., 1994, Mineral resources and sustainable development: a workshop. Elincourt Sainte-Marguerite (France), 5-7 May 1994, abstracts and background documents: BGS technical report WF/94/12-Documents du BRGM 237, 156+167 pp [English/French].

Cook, P J, 1996, Science in a market economy: BGS Technical Report WQ/96/1, 15 pp.

Council of the European Communities and Commission of the European Communities, 1992, Treaty on European Union: Office for Official Publications of the European Communities, Luxembourg.

Hageman, B P, 1987, Applied Quaternary studies: Episodes, v. 10, no. 1. pp. $46-48$.

Lumsden, G I, ed., 1992, Geology and the environment in Western Europe: a coordinated statement by the Western European Geological Surveys: Oxford, Clarendon.

Dr Richard Annells gained his PhD from the University of St Andrews. He has worked in the field with national geological surveys in Iceland, Canada, Iran, Pakistan, Turkey, Bolivia, Colombia, Egypt, Oman and Laos, mostly with the British Geological Survey. He was the BGS coordinator for European programmes and has directed the UK Research and Higher Education European Office in Brussels. He is now Secretary General of EuroGeoSurveys, based in Brussels.

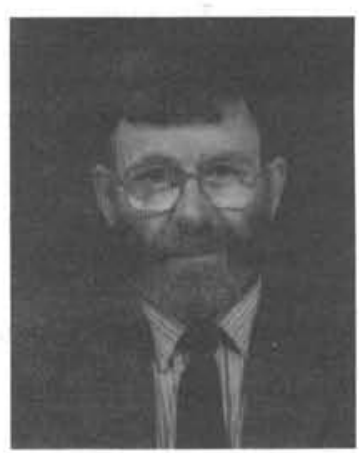

